\title{
ТЕХНІКО-ЕКОНОМІЧНЕ ОБГРУНТУВАННЯ ДОЦІЛЬНОСТІ СТВОРЕННЯ ЕНЕРГОТЕХНОЛОГІЧНОГО ЗАСОБУ НА БАЗІ ЗЕРНОЗБИРАЛЬНОГО КОМБАЙНА
}

\author{
Михайло Анеляк, к. т. н., Альвіан Кузьмич, к. т. н., \\ Олександр Грицака, к. т. н., Ігор Попадюк \\ Національний науковий иентр \\ «Інститут механізації та електрифікаиії сільського господарства», \\ вул. Вокзальна, 11, смт Глеваха, Васильківський р-н, Київська обл., Украӥна, \\ e-mail:sgricaka@ukr.net
}

https://doi.org/10.31734/agroengineering2021.25.099

\begin{abstract}
Анеляк М., Кузьмич А., Грицака О., Попадюк І. Техніко-економічне обгрунтування доцільності створення енерготехнологічного засобу на базі зернозбирального комбайна

Одним зі способів зниження сукупних витрат на виробництві зерна $є$ зменшення вартості парку сільськогосподарської техніки, зокрема за рахунок використання як енергозасобу зернозбирального комбайна та виконання комплексу робіт, не притаманних збиральній машині. У роботі означені основні положення щодо використання самохідного зернозбирального комбайна як енергозасобу, досліджено можливості завантаження його на інших сільськогосподарських роботах у пікові моменти весняного та осіннього періодів.

Проведено економічне оцінювання використання зернозбирального комбайна як енергозасобу замість трактора на виконанні сільськогосподарських робіт у пікові періоди роботи тракторів та вільних від роботи зернозбиральних комбайнів. Оцінено собівартість виконаних робіт за допомогою накладання на обсяг робіт умовного господарства. Для економічного оцінювання доцільності створення енергозасобу на базі зернозбирального комбайна було розглянуто сільськогосподарське підприємство лісостепової зони України, що спеціалізується на товарному виробництві зерна.

Для розрахунку техніко-економічних показників роботи енерготехнологічних засобів на базі трактора i зернозбирального комбайна 3 технологічних карт вирощування та збирання сільськогосподарських культур були вибрані технологічні операції, що виконуються за допомогою тракторів тягового класу 30 кН та зернозбиральних комбайнів, і побудовані подекадні графіки їх завантаження в розрахунку на 1000 га ріллі.

За умови використання одного зернозбирального комбайна як енергозасобу у весняний та осінній періоди польових робіт у розрахунку на 1000 га ріллі потреба в тракторах тягового класу 30 кН зменшиться на 1 одиницю.

Встановлено, що використання зернозбирального комбайна як енерготехнологічного засобу дасть змогу збільшити його річне завантаження в 1,5-2 рази та отримати річний економічний ефект у межах 70-100 грн/га.

Ключові слова: зернозбиральний комбайн, ефективність, енерготехнологічний засіб.
\end{abstract}

Aneliak M., Kuzmych A., Hrytsaka O., Popadyuk I. Feasibility substantiation of the expediency of creating an energy-technological unit based on a combine harvester

One of the ways to reduce the total costs of grain production is to reduce the costs of agricultural machinery fleet, in particular by using a combine harvester as an energy-technological unit and performing a set of works that are not typical for a harvesting machine. The paper indicates the main provisions on the use of a self-propelled combine harvester as an energy-technological unit, investigates the possibility of loading it on other agricultural work during the high seasons of spring and autumn.

An economic assessment of the use of a combine harvester instead of a tractor as an energy unit for performing agricultural work during peak periods of operation of tractors and grain harvesters free from work has been carried out. The cost of the work was done by imposing a conditional farm on the volume of work.

For economic assessment of the feasibility of creating an energy facility based on a grain harvester, an agricultural enterprise of the forest-steppe zone of Ukraine, specializing in commercial grain production, was considered.

To calculate the technical and economic indicators of operation of the energy-technological unit based on a tractor and a combine harvester, the authors of the research selected technological operations, performed by the tractors of a traction class $30 \mathrm{kN}$ and combine harvesters, from the technological maps of growing and harvesting agricultural crops. On their basis, ten-day schedules for loading tractors and combines per 1,000 hectares of arable land have been built.

Bye using one combine harvester as an energy unit in the spring and autumn periods of field work per 1,000 ha of arable land, it is possible to reduce the need for tractors of traction class $30 \mathrm{kN}$ by 1 unit.

It is established that the use of a combine harvester as an energy-technological unit will increase its annual load 1.5-2 times and allow to obtain an annual economic effect in the range of 70-100 UAH per hectare.

Key words: combine harvester, efficiency, energy-technological unit. 
Постановка проблеми. Сезонність виконання сільськогосподарських робіт накладає обмеження щодо завантаження сільськогосподарської техніки протягом року, особливо це стосується комбайнів. Ця проблема простоювання енергозасобу протягом 9-10 місяців у році, зростання металомісткості парку сільськогосподарських машин постійно стоїть перед провідними інститутами галузі та конструкторськими бюро. У загальній постановці вирішення цієї проблеми полягає у створенні універсальних енергозасобів тягового типу, які легко перелаштовувати під набір змінних модульно-блокових конструкцій для виконання всього комплексу робіт з вирощування i збирання зернових культур, кукурудзи, соняшнику, виконання вантажно-транспортних робіт і внесення добрив, що в кінцевому підсумку забезпечить зниження собівартості продукції.

Принцип модульно-блокового конструювання машин і різних технічних комплексів, сенс якого полягає у створенні універсального мобільного енергозасобу (УМЕЗ), для виконання численних технологічних операцій, що полягає у встановленні на нього змінних модулів, широко використовується в усіх галузях народного господарства.

У сільськогосподарському машинобудуванні однією 3 конструкцій модульно-блокового типу є зернозбиральний комбайн. Він складається 3 потужного самохідного енергозасобу (ходова частина, двигун, гідросистема, кабіна, система автоматичного управління і контролю), на який начіпляють змінні модулі для збирання врожаю багатьох сільськогосподарських культур: кукурудзи, соняшнику, зернобобових, сої, люпину, ріпаку, круп'яних культур, сорго, насінників трав тощо. Крім того, для збирання зернових за різними технологіями передбачені жниварки різної ширини захвату, підбирачі, засоби для збирання незернової частини врожаю (подрібнювач, копнувач, валковкладач).

Однак, незважаючи на досить об'ємний спектр універсалізації енергетичного засобу зернозбирального комбайна, ця модульно-блокова конструкція має істотний недолік - сумарне завантаження протягом року не перевищує трьох місяців.

Аналіз останніх досліджень і публікацій. Пошук конструкторських рішень створення універсальних конструкцій енергозасобів 3 можливістю ефективного використання на різних сільськогосподарських роботах та рівномірного завантаження їх упродовж року почався ще в 60-х роках минулого століття [2]. Результати робіт зі створення таких УМЕ3 і модульно-блокових комплексів (МБК) іноземних фірм втілилися в УME3 «Xerion» фірми «Claas» [13], МБК «Гітрак» - 200/300 - 250/350 к. с. фірми «Гілес», УМЕ3 «Полесье-250» фірми «Гомсільмаш». Але способи вирішення завдання зі створення модульно-блокових систем виявились недостатньо ефективними i вони не отримали широкого розповсюдження [8]. У сільськогосподарському машинобудуванні однією з конструкцій модульно-блокового типу $є$ зернозбиральний комбайн. Він складається 3 потужного самохідного енергозасобу, на який начіпляють змінні модулі для збирання врожаю багатьох сільськогосподарських культур [10]. Ідея створення мобільного енергетичного засобу на базі шасі зернозбирального комбайна була реалізована Таганрозьким державним спеціальним конструкторським бюро ГСКБ i заводом «Гомсільмаш». Створені цими підприємствами зразки мобільних енергомодулів мали низку недоліків $[4 ; 6 ; 15 ; 16]$.

Сьогодні існує практика створення мобільних енергетичних засобів (ME3) нових модифікацій із різними компонувальними схемами й можливостями їх використання для різних цілей $[5 ; 9 ; 11]$. Останнім часом і світові виробники 3 виготовлення спеціалізованих самохідних машин ставлять акценти на створення таких агрегатів на базі самохідних шасі [7]. ME3 - це багатофункціональна машина, у процесі використання якої діяльність людини здійснюється за двома напрямами, а саме: забезпечення експлуатації власне енергетичного засобу; забезпечення виконання технологічної операції або технологічного процесу. Відповідно до цього в праці [10] розрізняється технічна і технологічна експлуатація ME3. У такому разі проводити дослідження перспектив створення машинно-тракторних агрегатів (MTA) на базі МЕЗ різних типів, включаючи й самохідне шасі, доцільно, тільки розглядаючи технологічну експлуатацію енергозасобів. Існує кілька варіантів методик проведення подібних досліджень, які проаналізуємо далі. Авторами робіт $[1 ; 3 ; 12 ; 14]$ запропоновано оцінити рівень технологічності енергозасобу за такими узагальненими показниками: продуктивністю, агротехнічною якістю виконання технологічної операції та собівартістю робіт.

Постановка завдання. Мета нашого дослідження - обгрунтувати доцільність використання шасі зернозбирального комбайна як енергозасобу на виконанні різних сільськогосподарських робіт 
та провести економічну оцінку перспектив його створення.

Виклад основного матеріалу. Одним зі способів зниження сукупних витрат на виробництві зерна $\epsilon$ зменшення вартості парку сільськогосподарської техніки, зокрема за рахунок використання як енергозасобу зернозбирального комбайна та виконання комплексу робіт, не притаманних збиральній машині.

Проведено економічне оцінювання використання зернозбирального комбайна як енергозасобу замість трактора на виконанні сільськогосподарських робіт у пікові періоди роботи тракторів та вільних від роботи зернозбиральних комбайнів. Оцінено собівартість виконаних робіт за допомогою накладання на обсяг робіт умовного господарства.

Для економічного оцінювання доцільності створення енергозасобу на базі зернозбирального комбайна було розглянуто сільськогосподарське підприємство лісостепової зони України, що спеціалізується на товарному виробництві зерна. Структура посівних площ була прийнята відповідно до статистичних даних Держкомстату. У 2020 р. загальна площа сільськогосподарських угідь, що перебували в обробітку в сільськогосподарських підприємствах України усіх форм власності, становила 20746,9 тис. га, з них площа ріллі - 19476,1 тис. га (93,9\%). Структура посівних площ сільськогосподарських культур наведена на рис. 1.

Як видно з рис. 1, посівні площі культур, збирання яких проводять у сільськогосподарських підприємствах України за допомогою зернозбиральних комбайнів, становлять 18 млн га, або 94,3 \% у структурі посівних площ чи 86,9\% від площі сільгоспугідь.

Для організації виробництва розроблені технологічні карти вирощування та збирання сільськогосподарських культур. Розраховані показники річних затрат праці - ЗП, люд.-год.; річних витрат палива - ВП, кг. Для виконання розроблених технологічних процесів в агростроки обгрунтований необхідний технічний парк машин, що характеризується показниками (рис. 2): $\Pi_{3}-$ сумарна потужність технічного парку машин, кВт; $M_{3}$ - сумарна маса технічного парку машин, кг; $B_{3}$ - сумарна вартість технічного парку машин, грн.

Враховуючи, що в структурі технічного парку машин господарства наявні $n$ комбайнів масою $M_{K}$, вартістю $B_{K}$ і потужністю двигуна $\Pi_{K}$ кожен та $m$ тракторів масою $M_{T}$, вартістю $B_{T} \mathrm{i}$ потужністю двигуна $\Pi_{T}$, що близька до потужності двигуна комбайна $\Pi_{\kappa}$, можна припустити, що, замінивши $n$ зернозбиральних комбайнів на $m$ тракторів, можна вивільнити частину тракторів.

Річний економічний ефект від експлуатації нового комплексу машин у розрахунку на річний обсяг робіт у господарстві визначається за формулою

$$
E_{P K}=\left(\Pi-\Pi^{\prime}\right)+E_{\text {ЯK }},
$$

де $П, \Pi^{\prime}-$ сукупні витрати на виконання річного обсягу механізованих робіт відповідно базовим та новим машинно-тракторним парком (МТП), грн; $E_{Я \kappa}-$ річний економічний ефект, одержаний за рахунок зміни кількості та якості продукції в результаті експлуатації нового МТП, грн.

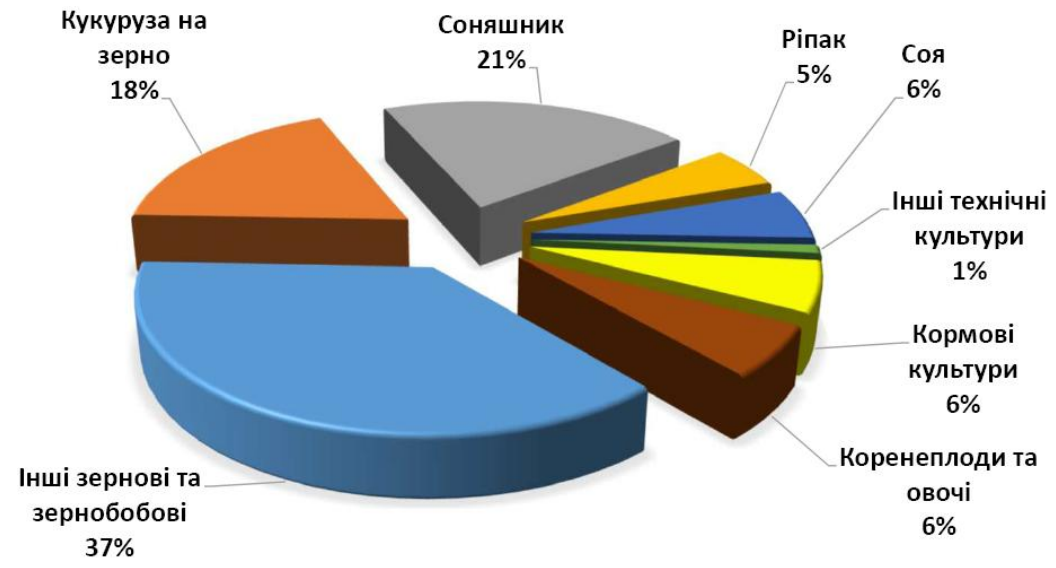

Рис. 1. Структура посівних площ у сільськогосподарських підприємствах України у 2020 р.

Fig. 1. Structure of cropping areas of agricultural enterprises of Ukraine in 2020 


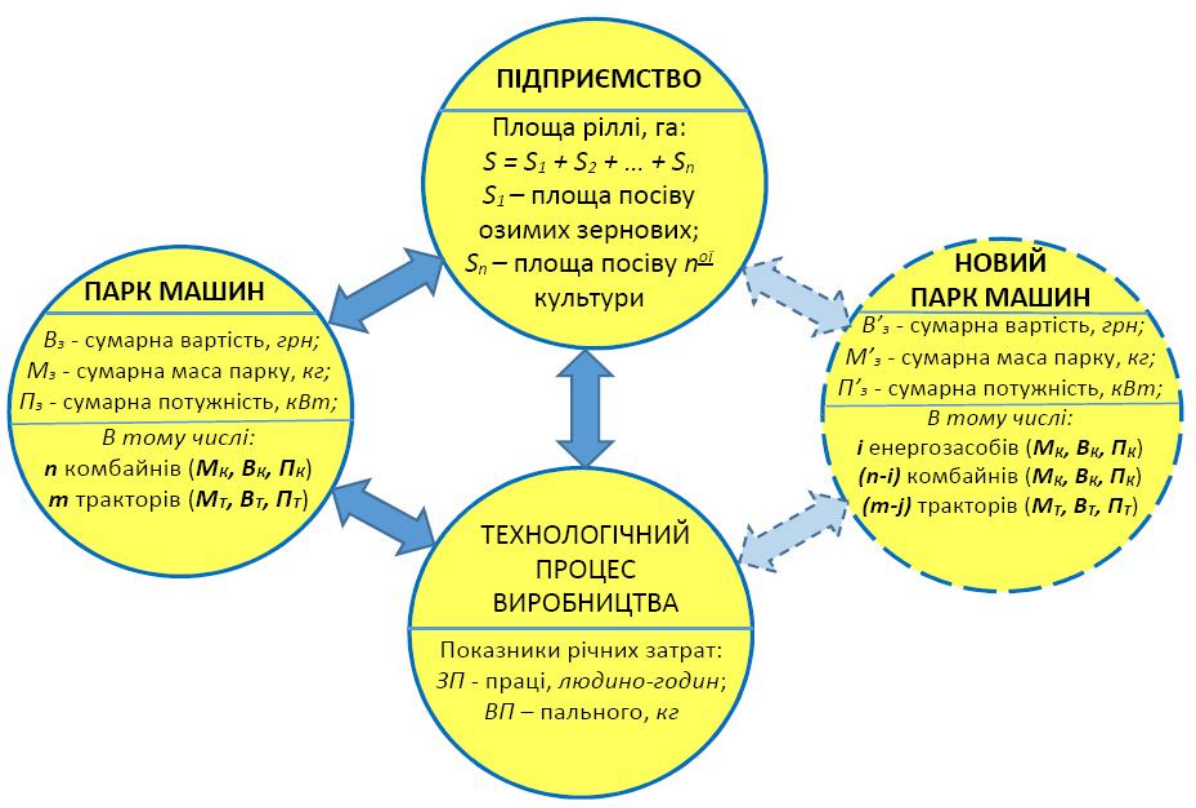

Рис. 2. Схема процесу виробництва зерна

Fig. 2. Scheme of a grain production process

Зробивши припущення, що якість та кількість продукції, отриманої в результаті використання базового МТП на базі трактора та МТП на базі зернозбирального комбайна, не змінюються, а коефіцієнти нормативних відрахувань на амортизацію, технічне обслуговування (TO) та ремонт, річні затрати на допоміжні матеріали, зберігання, страхування та монтування тракторів і комбайнів рівні між собою, отримаємо значення річного економічного ефекту від експлуатації нового комплексу машин:

$$
\begin{aligned}
& E_{P K}=\left(B_{3}-B_{3}^{\prime}\right) \cdot\left(H_{A}+H_{P}\right)- \\
& -\bigsqcup_{\Pi} \cdot\left(B \Pi^{\prime}-B \Pi\right),
\end{aligned}
$$

де $B_{3}{ }_{3}$ - сумарна вартість парку машин, в якому $i$ комбайнів замінено енергозасобами, що дозволяє вивільнити $j$ тракторів, грн; $H_{A}-$ узагальнений коефіцієнт (норма) відрахування на амортизацію парку машин; $H_{P}-$ узагальнений коефіцієнт (норма) відрахування на ТО та ремонт парку машин; $Ц_{\Pi}-$ комплексна ціна пального, грн/кг; $B \Pi, B \Pi^{\prime}$ - річні витрати пального існуючого та нового парку машин, кг.

$$
B_{3}^{\prime}=B_{3}-j \cdot B_{T}-i \cdot B_{K}+i \cdot B_{A},
$$

де $B_{T}$ - вартість трактора, грн; $B_{T}-$ вартість зернозбирального комбайна, грн; $B_{A}-$ вартість енергозасобу на базі зернозбирального комбайна, грн.

Враховуючи, що для забезпечення роботи зернозбирального комбайна як енергозасобу необхідне його дообладнання: зміцнення рами, оснащення причіпними пристроями, елементами механічного, гідравлічного та електроприводів сільськогосподарських машин, що агрегатуються, переобладнання ходової частини тощо, вартість та металомісткість енергозасобу на базі зернозбирального комбайна зросте порівняно 3 комбайном, тобто:

$$
B_{A}=K_{B} \cdot B_{K},
$$

де $K_{B}$ - коефіцієнт збільшення вартості енергозасобу на базі зернозбирального комбайна порівняно із зернозбиральним комбайном.

Враховуючи різні витрати палива трактора порівняно 3 комбайном, визначимо різницю в обсягах палива, необхідну для виконання обсягу робіт нового парку машин:

$$
B \Pi^{\prime}-B \Pi=\left(G^{\prime}-G\right) \cdot t_{A},
$$

де $G^{\prime}, G$ - відповідно годинна витрата палива MTA 3 енергозасобом на базі зернозбирального комбайна та трактором, кг/год; $t_{A}-$ річний обсяг робіт, який виконують зернозбиральні комбайни як енергозасоби, год.

$$
\begin{gathered}
\text { Отже, } 3 \text { урахуванням }(1-6) \text { отримаємо: } \\
\begin{aligned}
E_{P K} & =\left(j \cdot B_{T}-i \cdot\left(K_{B}-1\right) \cdot B_{K}\right) \cdot \\
& \cdot\left(H_{A}+H_{P}\right)-Ц_{\Pi}\left(G^{\prime}-G\right) \cdot t_{A} .
\end{aligned}
\end{gathered}
$$

За результатми проведених досліджень тягово-зчіпних властивостей було встановлено, що зернозбиральний комбайн КЗС-9 «Славутич» як енергозасіб зможе забезпечувати тягове зусилля в межах 25-32 кН [2]. Для розрахунку 
техніко-економічних показників роботи енерготехнологічних засобів на базі трактора і зернозбирального комбайна 3 технологічних карт вирощування та збирання сільськогосподарських культур були вибрані технологічні операції, що виконуються за допомогою тракторів тягового класу 30 кН та зернозбиральних комбайнів, і побудовані подекадні графіки їх завантаження в розрахунку на 1000 га ріллі (рис. 3, 4).

Як видно з рис. 3, пікові навантаження робіт на трактори класу 30 кН припадають на весняний (21.04-10.05) та осінній (21.09-31.10) періоди. Водночас пікове завантаження зернозбиральних комбайнів припадає на літній період роботи (11.07-10.08).

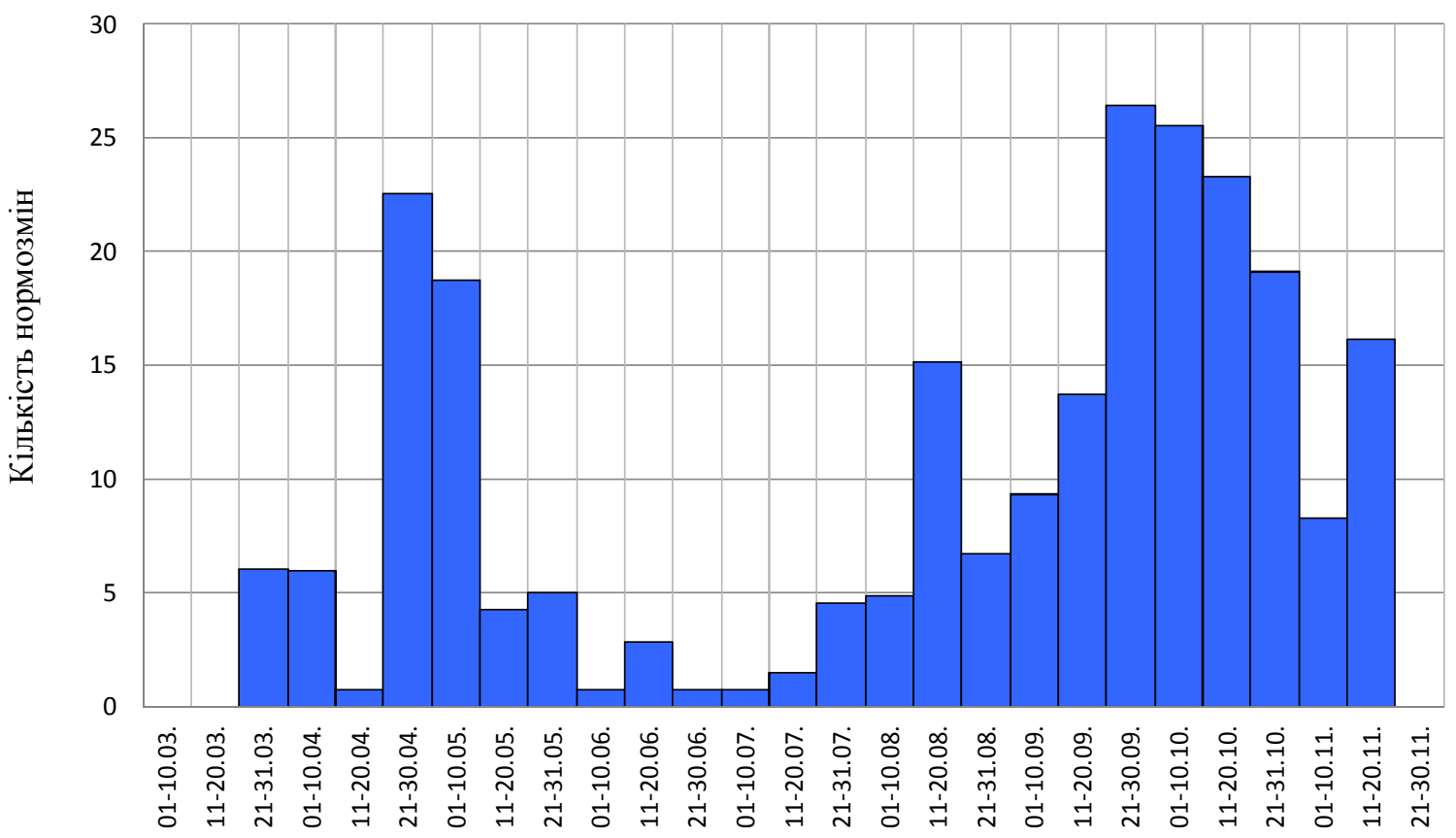

Рис. 3. Подекадний графік завантаження тракторів тягового класу 30 кН у розрахунку на 1000 га ріллі Fig. 3. Decade operation schedule of tractors of traction class $30 \mathrm{kN}$ per 1000 ha of arable land

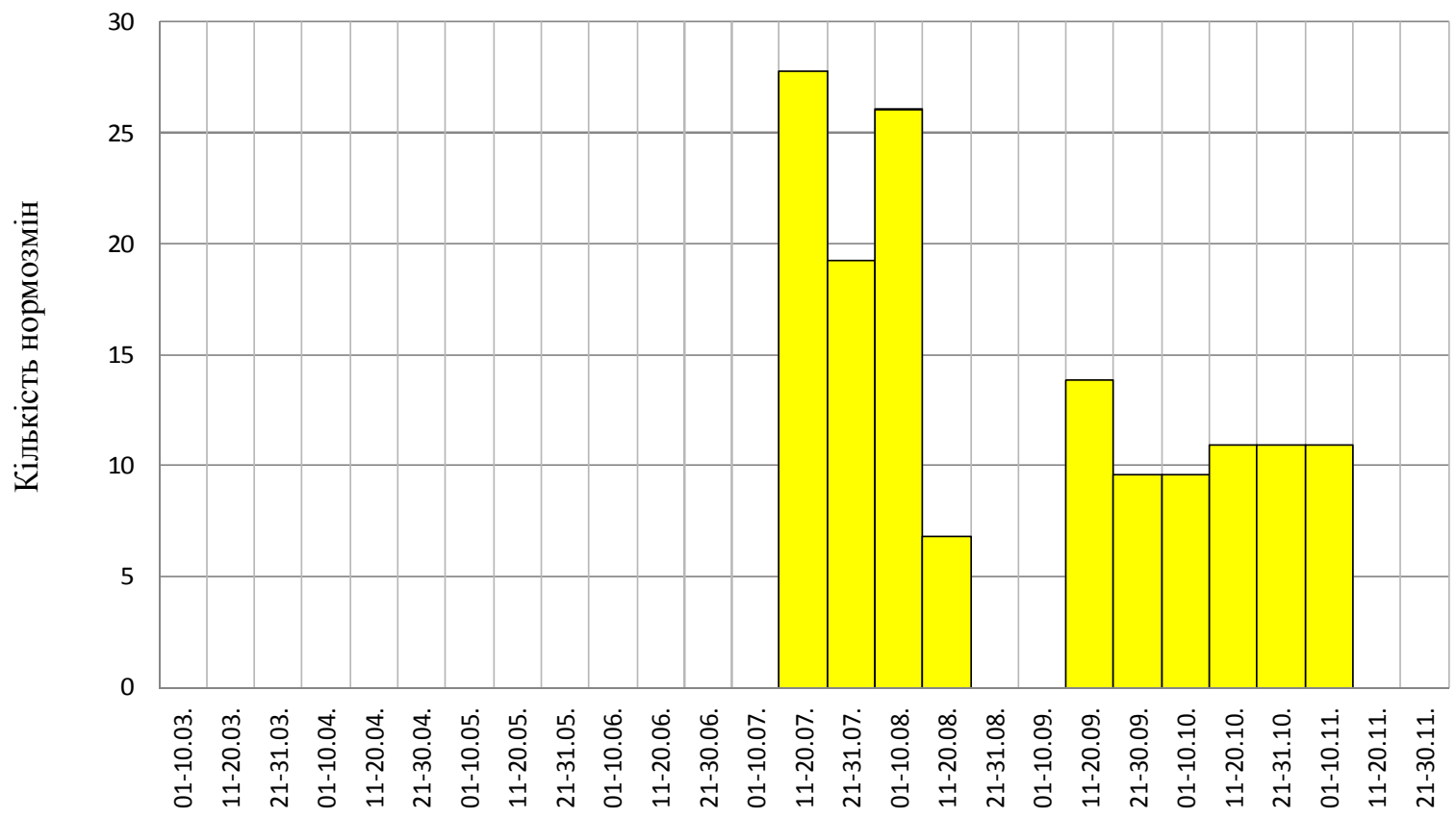

Рис. 4. Подекадний графік завантаження зернозбиральних комбайнів у розрахунку на 1000 га ріллі Fig. 4. Decade schedule of operation of combine harvesters per 1000 ha of arable land 
Виходячи 3 цього можна зробити припущення, що частину польових робіт у пікові моменти весняного та осіннього періодів можна виконати енергозасобами, створеними на базі зернозбиральних комбайнів. Це дозволить збільшити річне завантаження зернозбиральних комбайнів та зменшити необхідну кількість тракторів класу 30 кН для виконання польових робіт.

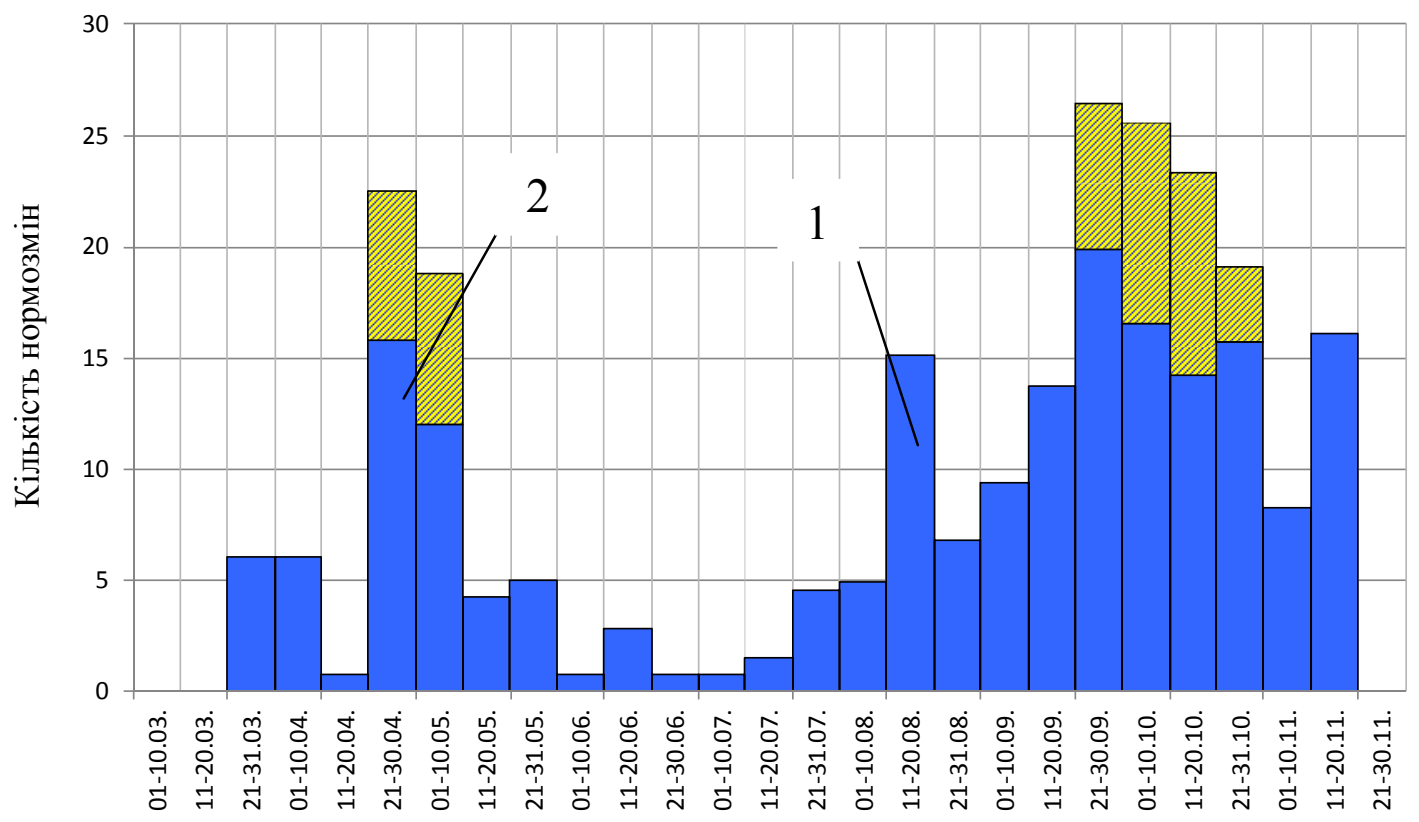

Рис. 5. Подекадний графік завантаження тракторів тягового класу 30 кН (1) та зернозбиральних комбайнів, використовуваних як енергозасоби (2), у розрахунку на 1000 га ріллі

Fig. 5. Decade operation schedule of tractors of traction class $30 \mathrm{kN}(1)$ and combine harvesters as energy units (2) per 1000 ha of arable land

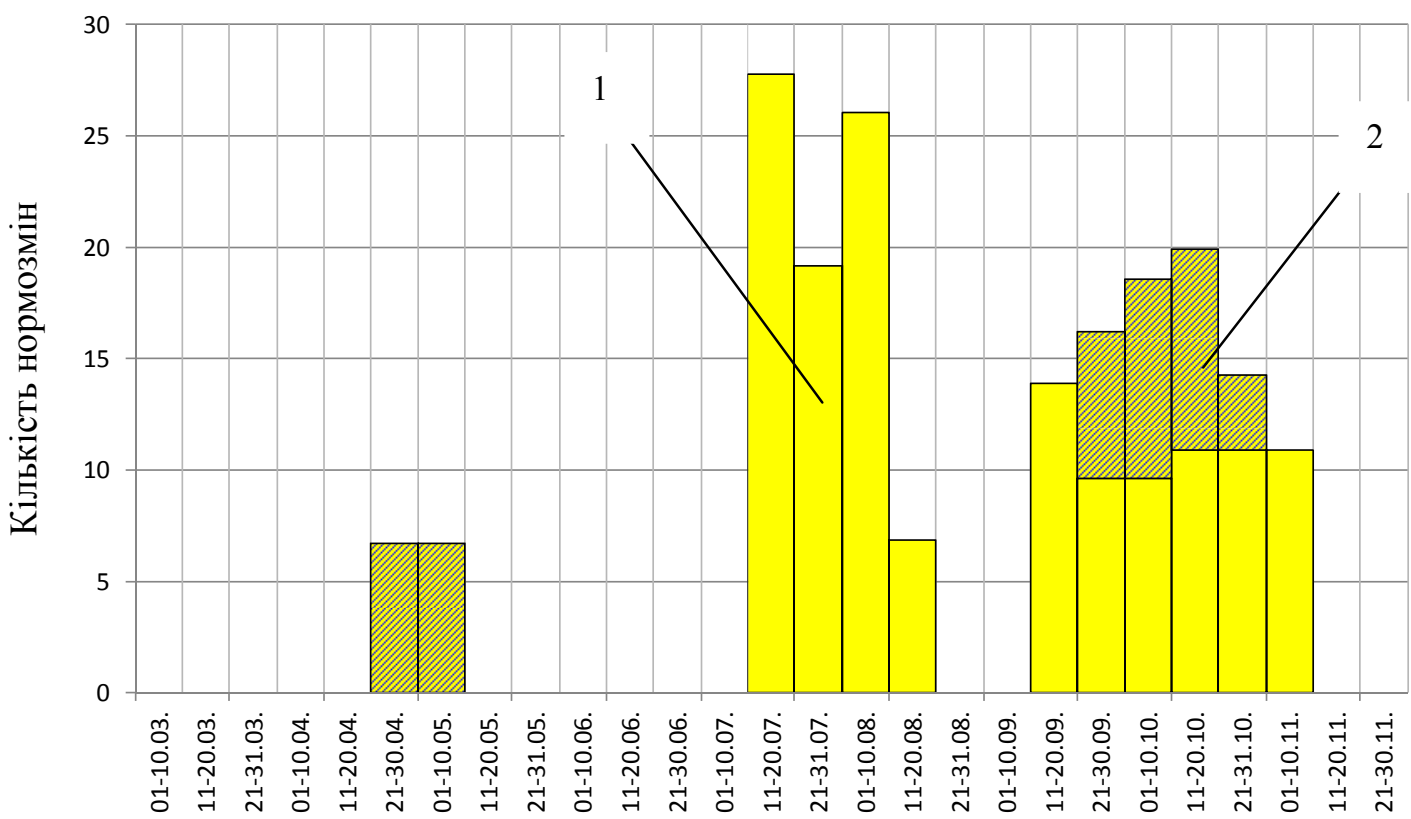

Рис. 6. Подекадний графік завантаження зернозбиральних комбайнів на збиранні врожаю (1) та використовуваних як енергозасоби (2) у розрахунку на 1000 га ріллі

Fig. 6. Decade schedule of engagement of combine harvesters at harvest (1) and as energy resources (2) per 1000 ha of arable land 
Згідно 3 цим припущенням ми вибрали технологічні операції передпосівного обробітку та дискування стерні, що можуть бути виконані енергозасобами, створеними на базі зернозбиральних комбайнів, та побудували подекадні графіки завантаження тракторів тягового класу $30 \mathrm{\kappa H} \mathrm{i}$ зернозбиральних комбайнів у розрахунку на 1000 га ріллі (див. рис. 5, 6) із врахуванням частки робіт, що може бути виконана за допомогою енергозасобів, створених на базі зернозбиральних комбайнів.

За даними розрахунків (див. рис. 2, 3) для виконання в агростроки польових робіт у розрахунку на 1000 га ріллі необхідно мати наявних 4 зернозбиральних комбайни типу КЗС-9 «Славутич» та 3 трактори тягового класу 30 кН. При цьому річне завантаження одного комбайна становитиме 255 мотогод, трактора тягового класу 30 кН - 567 мотогод.

За умови використання одного зернозбирального комбайна як енергозасобу у весняний та осінній періоди польових робіт у розрахунку на 1000 га ріллі потреба в тракторах тягового класу 30 кН зменшиться на 1 одиницю. При цьому річне завантаження одного комбайна становитиме 295 мотогод, трактора тягового класу 30 кН 705 мотогод, а зернозбирального комбайна 3 можливостями енергозасобу- 430 мотогод.

Результати розрахунку річного економічного ефекту наведені в таблиці.

Таблиця. Показники планової економічної ефективності використання енергозасобів на базі зернозбирального комбайна в розрахунку на 1000 га ріллі

Table. Indicators of planned economic efficiency of energy means use on the basis of a combine harvester per 1000 ha of arable land

\begin{tabular}{|c|c|c|c|}
\hline Показник & Позначення & $\begin{array}{l}\text { Розмір- } \\
\text { ність }\end{array}$ & Значення \\
\hline Вартість комбайна КЗС-9-1 «Славутич» & $B_{K}$ & тис. грн & 2735,00 \\
\hline Вартість трактора ХТЗ-150К-09-25-32 & $B_{T}$ & тис. грн & 1210,00 \\
\hline Кількість комбайнів МТП, замінених на енергозасіб & $i$ & & 1 \\
\hline $\begin{array}{l}\text { Кількість тракторів, вивільнених зі складу МТП за рахунок } \\
\text { використання енергозасобів на базі зернозбирального } \\
\text { комбайна }\end{array}$ & $j$ & & 1 \\
\hline $\begin{array}{l}\text { Коефіцієнт збільшення вартості зернозбирального } \\
\text { комбайна за використання його як енергозасобу порівняно } \\
\text { із зернозбиральним комбайном }\end{array}$ & $K_{B}$ & & 1,15 \\
\hline $\begin{array}{l}\text { Узагальнений коефіцієнт (норма) відрахувань на } \\
\text { амортизацію МТП }\end{array}$ & $H_{A}$ & & 0,10 \\
\hline $\begin{array}{l}\text { Узагальнений коефіцієнт (норма) відрахувань на } \\
\text { проведення ТО та ремонту МТП }\end{array}$ & $H_{P}$ & & 0,09 \\
\hline $\begin{array}{l}\text { Річний обсяг робіт, який виконують зернозбиральні } \\
\text { комбайни як енергозасоби, год }\end{array}$ & $t_{A}$ & годин & 290 \\
\hline $\begin{array}{l}\text { Збільшення годинної витрати палива МТА, створеного на } \\
\text { базі зернозбирального комбайна, порівняно з трактором }\end{array}$ & $\left(G^{\prime}-G\right)$ & кг/год & 7,5 \\
\hline Комплексна ціна пального & $Ц_{\Pi}$ & грн/кг & 22,5 \\
\hline $\begin{array}{l}\text { Річний економічний ефект від експлуатації нового } \\
\text { комплексу машин }\end{array}$ & $E_{P K}$ & тис. грн & 103,2 \\
\hline
\end{tabular}

Висновки. За умови використання одного зернозбирального комбайна як енергозасобу у весняний та осінній періоди польових робіт у розрахунку на 1000 га ріллі потреба в тракторах тягового класу 30 кН зменшиться на 1 одиницю.

Встановлено, що використання зернозбирального комбайна як енерготехнологічного засобу дасть змогу збільшити його річне завантаження в 1,5-2 рази та отримати річний економічний ефект у межах 70-100 грн/га.

\section{Бібліографічний список}

1. Адамчук В. В., Погорілий С. П., Кудринецький Р. Б., Коньок Н. М. Економічна ефективність використання мобільних сільськогосподарських агрегатів, сформованих на базі автомобільного шасі. Механізація та електрифікація сільського господарства: загальнодерж. зб. / ННЦ «ІМЕСГ». Глеваха, 2016. № 4 (103). C. 186-191.

2. Анеляк М. М., Кузьмич А. Я., Грицака О. М. Дослідження техніко-експлуатаційних показників енерготехнологічного засобу, створеного на базі шасі 
зернозбирального комбайна. Механізачія та електрифікація сільського господарства: загальнодерж. зб. / ННЦ «ІМЕСГ». Глеваха, 2020. № 11 (110). С. 171-177.

3. Днесь В., Кудринецький Р., Скібчик В. Щодо ефективності використання зернозбиральних комбайнів у різних природно-виробничих умовах. Вісник Львівського начіонального аграрного університету: агроінженерні дослідження. 2018. № 22. С. 99-106.

4. Жалнин Э. В., Годжаев 3. А., Флоренцев С. Н. Концептуальные принципы интеллектуальных сельскохозяйственных машин на примере зерноуборочного комбайна. Сельскохозяйственные машины и технологии. 2017. № 6. С. 9-16. doi: 10.22314/2073-7599-20176-9-16.

5. Макаренко М. Г., Макаренко О. М., Григораш О.Г. Підвищення тягових показників блочномодульних тягово-приводних агрегатів. Вісник ХНТУСГ. Технічні науки. 2014. Вип. 148. С. 295-304.

6. Масловский В. И. Совершенствование технологии уборки зерновых и зернобобовых культур с применением уборочно-почвообрабатывающего агрегата. Техника и оборудование для села. 2010. № 3. С. 18-19.

7. Надикто В. Перспективи тракторної енергетики та машинобудування в Україні (у порядку обговорення). Техніка і технологї̈ АПК. 2017. № 4. C. 11-14.

8. Панков А. А. Актуальність і перспективи створення універсальних модульних машин для вирощування зернових культур. Конструювання, виробництво та експлуатація сільськогосподарських машин. 2015. № 45, ч. 1. С. 239-246.

9. Погорілий С. Експериментальні дослідження тягових показників МЕ3-330 «Автотрактор» залежно від його конструкційних параметрів. Вісник Львівського національного аграрного університету: агроінженерні дослідження. 2018. № 22. С. 41-46.
10. Шейченко В. О., Недовєсов В. І., Кузьмич А. Я. Концептуальні основи розвитку комбайнобудування в Україні: показники типажу та структура базових моделей. Сільськогосподарські машини: загальнодерж. зб. наук. статей. Луцьк, 2020. Вип. № 45. C. $132-141$.

11. Шкарівський Г. В. Компонувальна схема самохідного шасі - реалії конструкції і напрями вдосконалення. Науковий вісник Національного університету біоресурсів і природокористування України. Серія: Техніка та енергетика АПК. 2015. Вип. 241. C. 236-246.

12. Шкарівський Г. В. Оцінювання створення машинно-тракторних агрегатів на базі самохідного шасі перспективного компонування. Науковий вісник Наиіонального університету біоресурсів $i$ природокористування Украӥни. Серія: техніка та енергетика АПК. 2017. Вип. 258. С. 302-311.

13. Elorza P., Izard M., Krus A., Iglesias B. Claas Xerion 4000 y olvídate de la roca madre. Vida Rural. 2018. Vol. MAQ. P. 8-19. URL: http://oa.upm.es/51322/ (Last accessed: 15.03.2021).

14. Hallam A., Eidman V., Morehart M., Klonsky K. Commodity Costs and Returns Estimation Handbook: A Report of the Area Task Force on Commodity Costs and Returns. Iowa State Univ., IA: [AAEA], 2000. 28 p.

15. Sirotin P. V., Sapegin A. G., Zlenko S. V. Experimental studies of ride quality of selfpropelled combine harvester. MATEC Web of Conferences. 2018. 226 p. doi: 10.1051/matecconf/201822601003.

16. Tang Z., Li Y., Cheng C. Development of multifunctional combine harvester with grain harvesting and straw baling. Spanish Journal of Agricultural Research. 2017. 15(1). P. 10. doi: 105424/sjar/2017151-10175.

Стаття надійщла 28.05.2021 